Cervi-9211116--2

WSRC-MS--92-280

DE93 002694

\title{
Analysis of lodine-129 in Aqueous Samples by Inductively Coupled Plasma-Mass Spectrometry ${ }^{(U)}$
}

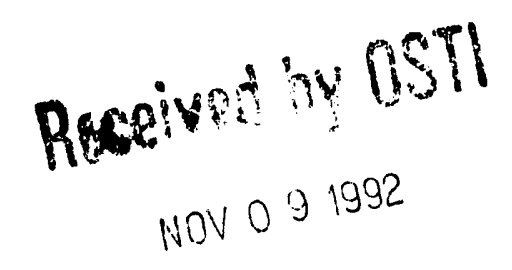

Donna M. Beals, Philippe Chastagner, and Patrick Turner

Westinghouse Savannah River Company

Savannah River Site

Aiken, SC 29808

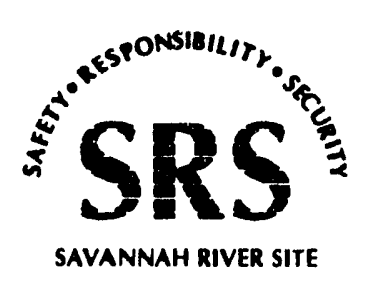

Prepared for the U. S. Department of Energy under contract No. DE-AC09-89SP18035 


\section{DISCLAIMER}

This report was prepared as an account of work sponsored by an agency of the United States Government. Neither the United States Government nor any agency thereof, nor any of their employees, makes any warranty, express or implied, or assumes any legal liability or responsibility for the accuracy, completeness, or usefulness of any information, apparatus, product, or process disclosed, or represents that its use would not infringe privately owned rights. Reference herein to any specific commercial product, process, or service by trade name, trademark, manufacturer, or ntherwise does not necessarily constitute or imply its endorsement, recommendation, or favoring by the United States Government or any agency thereof. The views and opinions of authors expressed herein do not necessarily state or reflect those of the United States Government or any agency thereof.

This report has been reproduced directly from the best available copy.

Available to DOE and DOE contractors from the Office of Scientific and Technical Information, P.O. Box 62, Oak Ridge, TN 37831; prices available from (615) 576-8401, FTS 626-8401.

Available to the public from the National Technical Information Service, U.S. Department of Commerce, 5285 Port Royal Rd., Springfield, VA 22161. 
WSRC-MS-92-280

\title{
Analysis of lodine-129 in Aqueous Samples by Inductively Coupled Plasma-Mass Spectrometry(U)
}

Donna M. Beals ${ }^{1}$, Philippe Chastagner', and Patrick Tumer ${ }^{2}$

\author{
${ }^{1}$ Westinghouse Savannah River Company \\ 2 Turner Scientific \\ Savannah River Site \\ Aiken, SC 29808 \\ Manchester, England
}

\footnotetext{
The information contained in this article was developed during the course of work under Contract No. DE-AC09-89SR18035 with the U. S. Department of Energy. By acceptance of this paper, the publisher and/or recipient acknowledges the U. S. Government's right to retain a nonexclusive, royalty-free license in and to any copyright covering this paper along with the right to reproduce, and to authorize others to reproduce all or part of the copyrighted paper.
} 
WSRC-MS-92-280

\title{
Analysis of Iodine-129 in Aqueous Samples \\ by Inductively Coupled Plasma - Mass Spectrometry
}

Donna M. Beals ${ }^{1}$, Philippe Chastagner ${ }^{1}$, and Patrick Turner ${ }^{2}$

${ }^{1}$ Westinghouse Savannah River Company

Savannah River Site

Aiken, SC 29808

2 Turner Scientific

Manchester

England

\begin{abstract}
An inductively coupled plasma - mass spectrometry (ICP-MS) method was developed to determine the ${ }^{129}$ I content in aqueous environmental samples. Due to interference from xenon, direct measurement of ${ }^{129} \mathrm{I}$ could not be made on the ICP-MS. An ion-exchange technique is used to concentrate the Iodine from one liter samples to $30 \mathrm{~mL}$. The $30 \mathrm{~mL}$ eluant from the anion-exchange column is then introduced to the ICP-MS. The detection limit of the procedure is $\leq 0.5 \mathrm{pCi} / \mathrm{L}$.
\end{abstract}

Several samples from the Savannah River near the Savannah River Site (SRS) have been analyzed for ${ }^{129} \mathrm{I}$ by this procedure. Concentrations of ${ }^{129} \mathrm{I}$ in the Savannah River ranged from $0.05 \pm 0.12$ to $0.21 \pm 0.49 \mathrm{pCi} / \mathrm{L}(95 \% \mathrm{CL})$. Below a seep ge basin, in Four Mile Creek on the Savannah River Site, ${ }^{129}$ I concentrations were as high as $2.31 \pm 1.22 \mathrm{pCi} / 1$. Before exiting the SRS the ${ }^{129} \mathrm{I}$ concentration had decreased to $0.30 \pm 0.16 \mathrm{pCi} / \mathrm{L}$ by dilution in Four Mile Creek.

\section{Introduction}

Nuclear fission processes produce ${ }^{129}$. It may be released to the environment by nuclear reactors and separation processes. Analysis of environmental samples is required to ensure that the ${ }^{129} \mathrm{I}$ concentration in the environment around nuclear facilities does not exceed dose limits as set forth in DOE Orders 5400.1 and 5400.5. Aqueous samples of ${ }^{129}$ I had been measured previously at the SRS by neutron activation techniques (Anderson, 1980). There are currently no operating reactors at the SRS to perform the neutron activation analysis, thus a new method for detection of ${ }^{129} \mathrm{I}$ had to be developed.

Mass spectrometric techniques are more sensitive than counting techniques for radionuclides with half-lives of over 1000 years. The half-life of ${ }^{129} \mathrm{I}$ is $1.6 \times 10^{7}$ years. The mass spectrometric technique chosen for measuring ${ }^{129} \mathrm{I}$ was inductively coupled plasma - mass spectrometry (ICP-MS). At the Savannah River Technology Center (SRTC), at the SRS, we are using a Turner TS Sola ICP-MS to measure ${ }^{129} \mathrm{I}$ in aqueous samples. The detection limit of the instrument is $3 \mathrm{ppt}(0.53 \mathrm{pCi} / 1)$ of ${ }^{129} \mathrm{I}$, providing we have Xenon-free Argon. To date we have been unable to obtain sufficiently Xenon-free 
Argon, thus our detection limit is approximately $17 \mathrm{pCi} / \mathrm{L}{ }^{129} \mathrm{I}$. To ensure that the dose limit in DOE Order 5400.1 is not exceeded and to calculate the environmental impact of the SRS, a detection limit of $\leq 1.0 \mathrm{pCi} / \mathrm{L}$ of ${ }^{129} \mathrm{I}$ was desired. To reach the desired detection limit of $\leq 1.0 \mathrm{pCi} / \mathrm{L}$ we have developed a concentration technique which provides a 33-fold concentration factor, giving us a procedural detection limit of $\leq 0.5$ $\mathrm{pCi} /$.

\section{Concentration Procedure}

The concentration procedure is similar to that used for the previous SRTC neutron activation technique. The natural Iodine in the sample is used as a yield monitor. One milliliter of $5 \% \mathrm{NaOCl}$ per liter of sample is added to ensure all of the iodine exists in the oxidized state. The Iodine is then reduced by adding $5.0 \mathrm{~mL}$ of $1 \mathrm{M} \mathrm{NH} \mathrm{N}_{2} \mathrm{OH}-\mathrm{HCl}$ and 2.0 $\mathrm{mL}$ of freshly made $\mathrm{NaHSO}_{3}$ per liter. The $\mathrm{pH}$ of the sample is adjusted to $6.4-6.6$ with $\mathrm{NaOH}$ and the Iodine concentrated on $2.0 \mathrm{~mL}$ of Bio-Rad AG 1 X8, Cl- form anionexchange resin. $30 \mathrm{~mL}$ of $4 \mathrm{M} \mathrm{HNO}_{3}$ was used to elute the Iodine from the resin (Dolan, et al. (1991). The $4 \mathrm{M} \mathrm{HNO}_{3}$ eluant is introduced directly into the ICP-MS for the analysis.

\section{Inductively Coupled Plasma - Mass Spectrometer Analysis}

Figure 1 shows the spectrum of a $10 \mathrm{ppb}{ }^{127} \mathrm{I}$ (natural Iodine) solution. The peaks at mass 129,131 , and 132 are xenon, at $26.4 \%, 21.2 \%$, and $26.9 \%$ respectively. Figure 2 shows a standard with a $129 / 127$ Iodine radio of 0.1 , the ${ }^{127} \mathrm{I}$ at $10 \mathrm{ppb}$. When making ${ }^{129} \mathrm{I}$ measurements, the ${ }^{131} \mathrm{Xe}$ peak is monitored to correct for ${ }^{129} \mathrm{Xe}$ at $\mathrm{n} / \mathrm{z}=129$. In natural samples ${ }^{132} \mathrm{Ba}$ may bias a ${ }^{132} \mathrm{Xe}$ based correction at $\mathrm{n} / \mathrm{z}=129$, thus the smaller ${ }^{131} \mathrm{Xe}$ peak was chosen for making the ${ }^{129} \mathrm{Xe}$ correction.

The TS Sola ICP-MS has two detectors: a Faraday detector is used for counting signals $>1 \times 10^{6}$ counts per second, and a multiplier for counting smaller signals. After concentration of an aqueous sample the count rate is too high for the ${ }^{127} \mathrm{I}$ to be counted on the multiplier detector; however, the ${ }^{129} \mathrm{I}$ must be counted on the multiplier to achieve the desired sensitivity. To obtain the $129 / 127$ ratio, indium is used as an internal standard. Indium has two isotopes, 113 at $4.3 \%$ and 115 at $95.7 \%$. By correctly choosing the indium concentration, the ${ }^{115}$ In and ${ }^{127} \mathrm{I}$ can be counted on the Faraday detector, while the ${ }^{113} \mathrm{In},{ }^{129} \mathrm{I}$, and ${ }^{131} \mathrm{Xe}$ are counted on the multiplier detector. By setting the Faraday and multiplier detector sensitivities to 1.0 for both elements, and setting the isotope equations so that the ${ }^{127} \mathrm{I}$ isotopic abundance is $100 \%$ on the Faraday detector and the ${ }^{129} \mathrm{I}$ isotopic abundance is $100 \%$ on the multiplier, the $129 / 12 \%$ Iodine ratio can be determined directly from the ICP-MS results. The $129 / 127$ ratio can then be multiplied by the Iodine concentration in the origina! sample to obtain the ${ }^{129}$ I concentration of the original sample.

\section{Sample Results}

Blanks were prepared by adding a known amount of Iodine to deionized water. The 129/127 Iodine ratios and calculated 129I concentrations are shown in Table 1. These values are consistent with our predicted detection limit of $\leq 0.5 \mathrm{pCi} / \mathrm{L}$. Samples are 
collected quarterly from the Savannah River above and below the SRS. The results from the first two quarters show ${ }^{129}$ I concentrations below our detection limit (see Table 2.).

Near the F- and H- separations areas on the SRS are seepage basins known to have elevated concentrations of ${ }^{129} \mathrm{I}$ (Anderson, 1980). The headwater of Four Mile Creek is above the seepage basins; the creek is just under 15 miles long. At approximately river mile 3 the creek passes the seepage basins. As seen in Figure 3, the ${ }^{129}$ I concentration in Four Mile Creek increases dramatically upon passing the seepage basins. By the time the creek exits the SRS and enters the Savannah River, the ${ }^{129}$ I concentrations are at the procedure detection limit, similar to the Savannah River values above the SRS.

\section{Conclusions}

At the SRTC we have developed a method to analyze aqueous samples for ${ }^{129}$ I by ICP. MS. We are currently measuring the ${ }^{129}$ I concentrations in streams on the SRS and in the adjacent Savannah River. We have just added an ultrasonic nebulizer to our ICP-MS which appears to have decreased the Xenon interference. By using the ultrasonic nebulizer and by increasing the sample size we hope to decrease our detection limit to $<0.1 \mathrm{pCi} / \mathrm{L}$.

\section{Acknowledgments}

The authors would like to extend their thanks to Sharon Redd, Senior Laboratory Technician, who performed many of the chemical concentrations for these samples.

The information contained in the manuscript was developed during the course of work done under Contract No. DE-AC09-89SR18035 with the U.S. Department of Energy.

\section{References}

Anderson, T.J., "Methodology for the Determination of Environmental I-129 and Tc-99", Effluent and Environmental Radiation Surveillance, ASTM STP 698, J. J. Kelly, Ed., American Society for Testing and Materials, 1980, pp. 84-94.

Dolan, S.P., Sinex, S.A., Capar, S.G., Montaser, A., and Clifford, R.H., "On-Line Preconcentration and Volatilization of Iodine for Inductively Coupled Plasma Atomic Emission Spectrometry", Analytical Chemistry, 63, 1991, pp. 2539-2542. 
Table 1. Iodine-129 Blank Results

\section{Sample Number $\quad 129 / 127$ Iodine Ratio}

${ }^{129} \mathrm{I} \mathrm{pCi} / \mathrm{L}$

1

2

3.

4

$1.23 \times 10^{-6}$

$1.00 \times 10^{-6}$

$1.49 \times 10^{-6}$

$0.94 \times 10^{-6}$
0.328

0.314

0.144

0.173

mean

$0.24 \pm 0.10(1 \sigma)$ 
Table 2. Iodine-129 Concentration in the Savannah River

Location 1st Quarter (pCi/L)* 2nd Quarter $(\mathrm{pCi} / \mathrm{L})^{*}$

Shell Bluff

$$
\begin{aligned}
& 0.05 \pm 0.12 \\
& 0.16 \pm 0.58 \\
& 0.21 \pm 0.49 \\
& 0.12 \pm 0.24
\end{aligned}
$$

Below Vogtle

$0.16 \pm 0.47$

$0.11 \pm 0.42$

$0.12 \pm 0.28$

Highway 301 Bridge

* 95\% CL 
Figure 1. 10 ppb Iodine-127 (Natural lodine)

\section{0 ppb std}

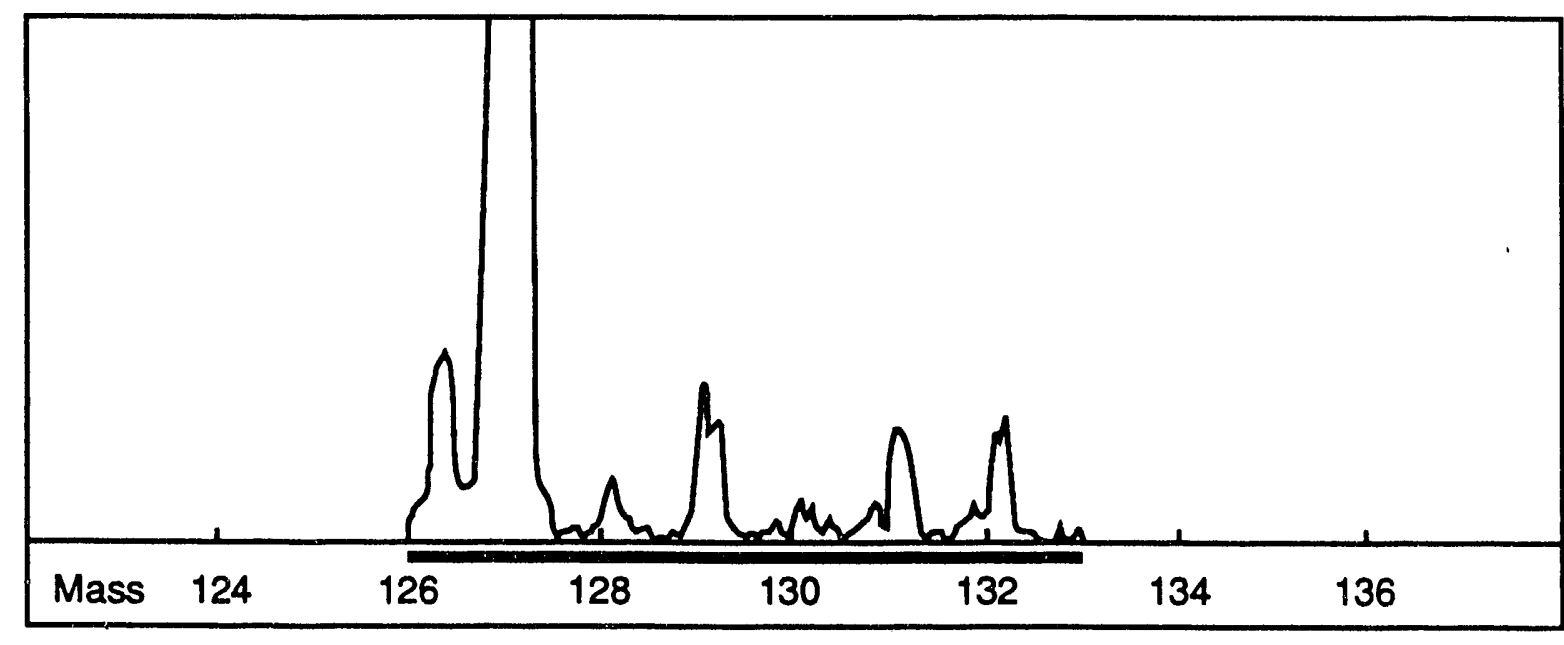

Dwelltime per Channel : $32 \mathrm{~ms}$

Channells per AMU

Number of Passes
$: 16$

$: 8$

M92J005.01 
Figure 2. 10 ppb Iodine-127 Standard $-129 / 127$ Ratio $=0.1$

$129 / 127 \mathrm{I}=0.1$ at $10 \mathrm{ppb} \mathrm{I-127}$

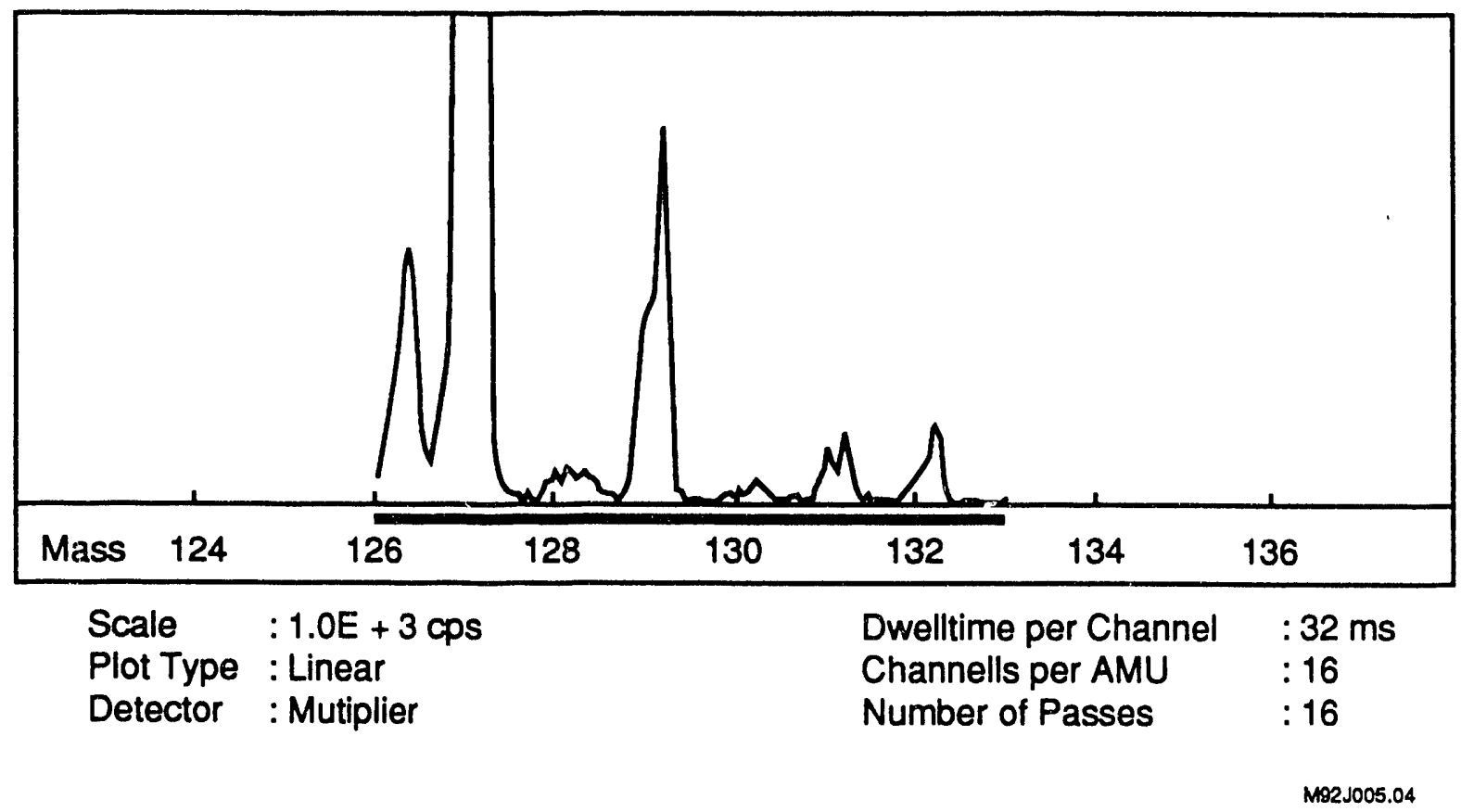


Figure 3. Iodine-129 Concentration in Four Mile Creek

I - $129 \mathrm{pCi} / \mathrm{L}$

Four Mile Creek

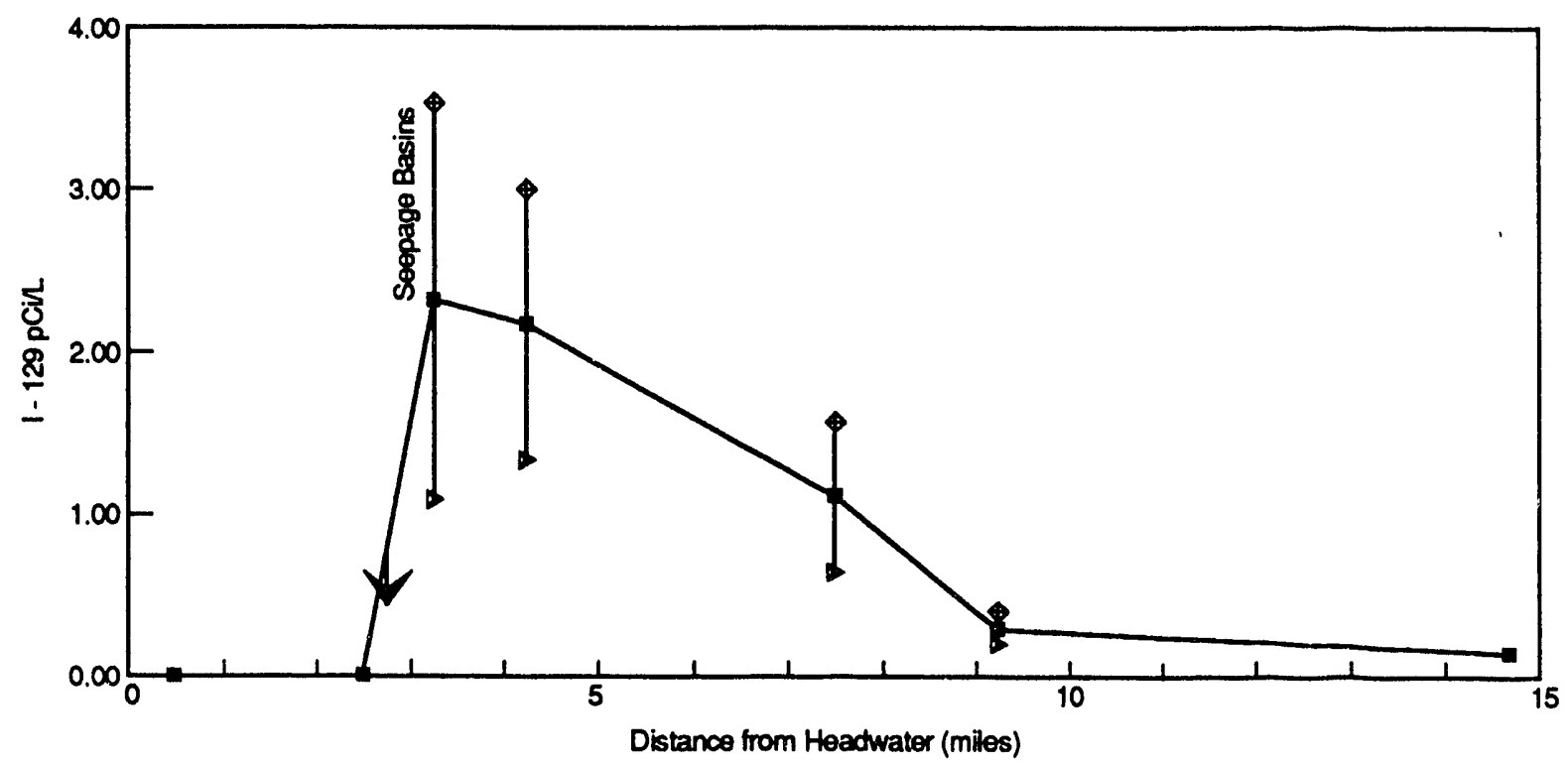

M92.J005.05 

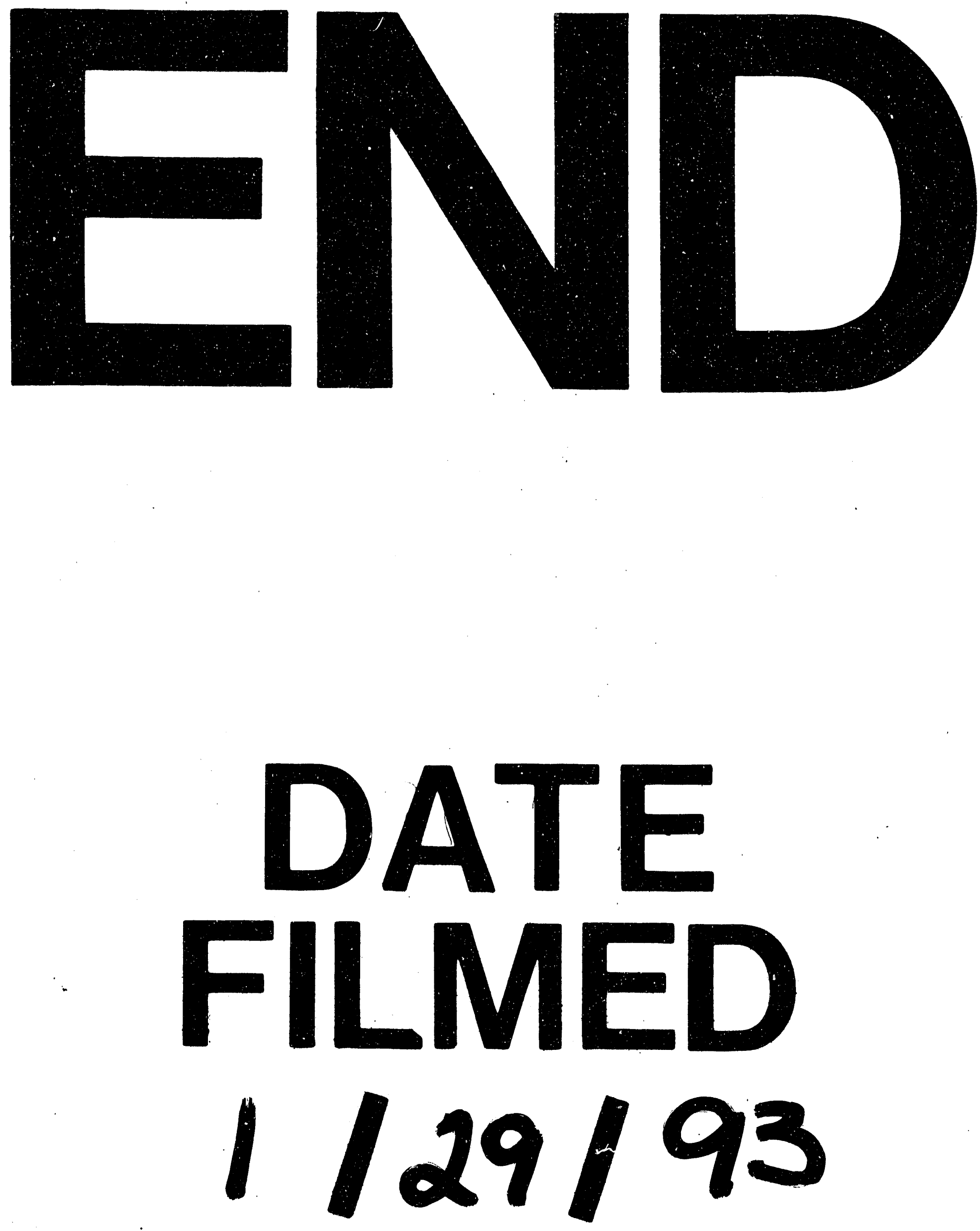